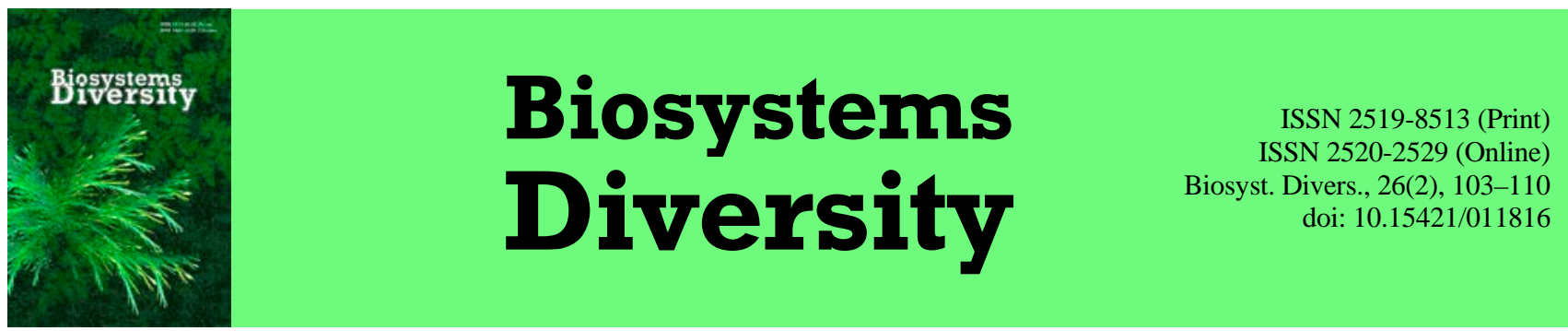

\title{
Formation of the structure of microbiocenoses of soils of agroecosystems depending on trophic and hydrothermal factors
}

\author{
O. S. Demyanyuk*, V. P. Patyka**, O. V. Sherstoboeva*, A. A. Bunas* \\ *Institute of Agroecology and Environmental Management NAAS, Kyiv, Ukraine \\ **D. K. Zabolotny Institute of Microbiology and Virology NAS of Ukraine, Kyiv, Ukraine
}

\section{Article info \\ Received 19.03.2018 \\ Received in revised form 11.05.2018 \\ Accepted 14.05.2018}

Institute of Agroecology and Environmental Management NAAS, Metrologichna st., 12, Kyiv, 03143, Ukraine.

Tel.: +38-067-680-12-43.

E-mail:demolena@ukr.net

D. K. Zabolotny Institute

of Microbiology and Virology NAS of Ukraine,

Acad. Zabolotny st., 154

Kyiv, 03143, Ukraine.

Tel.: +38-098-354-25-00.

E-mail:

patykavolodymyr@gmail.com

\begin{abstract}
Demyanyuk, O. S., Patyka, V. P., Sherstoboeva, O. V., \& Bunas, A. A. (2018). Formation of the structure of microbiocenoses of soils of agroecosystems depending on trophic and hydrothermal factors. Biosystems Diversity, 26(2), 103-110. doi:10.15421/011816
\end{abstract}

Ground soil, as the product primarily of the activity of microbiota, is under the permanent influence of ecological and anthropogenous factors. Soils are especially subject to pressure in agroecosystems, which increases due to the considerable fluctuation of climate system parameters. Using graph analysis, we have estimated the results of multiyear monitoring research on the functioning of microbiocenoses of three soil types in agroecosystems depending on the fertilizing and hydrothermal mode. It enabled us to detect peculiarities of formation of the structure soil microbiocenoses and to better understand ecologically important relations between functional groups of microorganisms in the soil depending on action of different factors. It has been determined that neither application of organic and mineral fertilizers into chernozem nor action of hydrothermal factors (temperature air and humidity) is a crucial characteristic of changing in the structure of its microbiocenosis. Microorganisms-producers of exopolysaccharides, which have a strong relationship with all trophic groups of microorganisms as they are their structural components, turned out to be the main block constructing factor, which is due to their strong influence on total content of microbal mass in soil. For soil of agroecosystems with dark-grey type of soil characteristic of content of total biomass of microorganisms is a basis for block constructing gremium, which affirms the state of microbiocenosis and processes occurring there under the action of researched biotic and abiotic factors. Microbiocenosis of sod-podzolic soil, unlike the other researched types of soils, reacted distinctly on applying of fertilizer and depended on the action of hydrothermal factors. Contrast in the range of hydrothermal regime caused a chaotic character of interaction between the basic characteristics in microbiocenosis of sod-podzolic soil with appearance of a direct and mediated relationship among them. Regardless of changes in hydrothermal factors , interactions between characteristics of total microbial mass content, eutrophic microorganisms, which use mineral and organic forms of nitrogen, and producers of exopolysaccharides were stable. It has been proved that estimating of ecological state of soil and influence of applicable agromeasures on it should be conducted according to the indices of total microorganism biomass content in the soil and correlation between the number of microorganisms which form the graph gremium.

Keywords: soil microorganisms; graph-analysis; hydrothermic regime; fertilizer

\section{Introduction}

The qualitative and quantitative compound of microbiocenoses is essential for a number of biogeochemical processes and determines the fertility and functioning of the ecosystem in general (Torsvik \& Ovreas, 2002; Wall, 2012; Aislabie \& Deslippe, 2013; Nannipieri et al., 2017). Due to the large surface of contact with the environment, microorganisms are extremely sensitive to variable living conditions, and their high tempos of reproduction allows one to determine the changes which develop due to ecological (Kuramae et al., 2012; De Vries et al., 2013) and anthropogenic (Treonic et al., 2010; Sheibani \& Ahangar, 2013) factors in a short period. Therefore, microbiological and biochemical activity of soils is recommended to be used as a sensitive parameter or an indicator of their ecological condition and during evaluation of the consequences of anthropogenic loading (Andreyuk, 1981; Demyanyuk et al., 2017; Sherstoboeva et al., 2017).

A strong impact on the biological processes in the soil of an agroecosystem is caused by usage of different agrotechnologies, particularly methods of mechanical processing (Hydbom et al., 2017) and use of different types of fertilizers (Geisseler \& Scow, 2014; Rehman et al., 2016). Such conditions cause structural and functional changes in the composition of microbial formations: change in the dominant species, strategies of their population development, patterns of microbial trans- formation of the organic substance of soil, etc. (Zornoza et al., 2009; Zhao et al., 2015).

Increase in the impact of different agricultural procedures on the soil environment and its unpredictable consequences occur in the conditions of changes in climate, which affect the distribution of species of organisms and their interaction (Singh et al., 2010). In terrestrial ecosystems, this range of changes depends on the interaction of terrestrial and subterranean groups of organisms, which affect the species composition, quantitative characteristics, processes in the ecosystem, and also the relations inside groups and ecosystems (van der Putten, 2012). According to scientists predictions, a change in the interaction of species in response to the changes in the climatic parameters along with anthropogenic factors will have a significant effect on the biodiversity and functions of terrestrial ecosystems (Walther et al., 2002; Gottfried et al., 2012; Langley \& Hungate, 2014).

Hydrothermal factors affect the vitality of microorganisms and their activity in the soil both directly and indirectly. Temperature and moisture are important components of the ecological conditions, which affect the structure of microbiocenoses and the activity of different taxa in the group and regulate the main soil-biological processes (Steinweg et al., 2013; Xiong et al., 2014). However, the trend and the extent of these responses are not yet fully determined. In particular, the reaction of microbial groups in the soil to changes in the atmospheric concentration of $\mathrm{CO}_{2}$ can be 
either positive or negative, and the following general tendencies in them remain unstudied (Lesaulnier et al., 2008).

Significant directions in the contemporary studies on the ecology of microorganisms are the study of the structure of microbial groups in relation to the impact of ecological and anthropogenic factors (Stegen et al., 2013), determining the relations and interaction between different organisms in the subterranean environment, including using methods of mathematiccal modeling (Barberan et al., 2012), functional stability of microbiocenoses and their genetic diversity (Bissett et al., 2013; Loreau \& de Mazancourt, 2013; Thibaut \& Connolly, 2013; Tsiafouli et al., 2015). At the same time, the interaction of the members of the microbial groups is determined as an initial factor, and the determination of the mechanisms of interaction of microorganisms and their consequences are considered important for defining the principles of dynamic in the abundance of microbiota, understanding of their functioning in natural conditions and for creating effective artificial microbiocenoses (Konopka et al., 2015).

The list of microbiological and biochemical parameters for adequate evaluation of the ecological condition of the soil in agroecosystems remains insufficiently discussed and not fully substantiated. These issues could be solved using mathematical methods broadly applied in practice for explaining particular properties of a biological object and processes which occur in it (Aitkenhead, 2016). However, as a result of the complex structure of agroecosystems, the usage of the traditional mathematical methods and development of corresponding models is a rather complicated task for most factors are highly stochastic in behaviour and studied insufficiently (Bradford \& Fierer, 2012; Bui \& Henderson, 2013; Song et al., 2014; Calzolari et al., 2016; Vereecken et al., 2016). Knowing which factors will have the dominating impact on the microbial groups, their reaction and changes in the structures of the microbial grouping of the soil, one can make more accurate predictions of the ecosystemic processes in the condition of climate changes compared to the predictions based on the results and data on the environment only. The objective of this study was to determine the peculiarities of formation of the microbiocenosis of the soil in agroecosystems in relation to the type of soil, usage of fertilisers and hydrothermal regime of the analyzed period and to determine the lowest number of microbiological indicators which characterise the ecological condition of soil in the agroecosystems.

\section{Material and methods}

The study was conducted in the Laboratory of Ecology of Microorganisms at the Institute of Agroecology and Environmental Management of National Academy of Agrarian Sciences of Ukraine. The initial data for the analysis, calculations and mathematical analysis were the results of multi-year studies of soil microbiocenoses in stationary field experiments of the National Academy of Agrarian Sciences of Ukraine (Table 1) during 2001-2015, which allowed us to evaluate the impact of different factors (edaphic, climatic, agrotechnical) on the ecological condition of soil.

Table 1

Agrochemical characteristic of soil in stationary field experiments, $0-20 \mathrm{~cm}$

\begin{tabular}{lrrrrc}
\hline \multicolumn{1}{c}{ Type of soil } & \multicolumn{3}{c}{$\begin{array}{c}\text { Hu- } \\
\mathrm{pH}_{\text {salt }} \begin{array}{c}\text { mus, } \\
\text { \% }\end{array}\end{array}$} & \multicolumn{4}{c}{ Content, mg/kg of soil } \\
nitrogen which & $\begin{array}{c}\text { active } \\
\text { easily hydrolises }\end{array}$ & phosphorus & potassium \\
\hline $\begin{array}{l}\text { Deep low-humus } \\
\text { chernozem }\end{array}$ & 6.2 & 4.2 & 120 & 159 & 110 \\
$\begin{array}{l}\text { Podzolized dark-grey } \\
\text { Sod-podzolic loamy }\end{array}$ & 5.8 & 1.8 & 117 & 235 & 88 \\
sand soil & 4.9 & 1.1 & 74 & 170 & 68 \\
\hline
\end{tabular}

The soil samples of the agroecosystems were selected from the 0 $20 \mathrm{~cm}$ layer and rhizosphere of the plants over the period when the system reached its climax - stable, balanced state (late June - early July). For the microbiological analyses, we selected the soil samples from each variant of the experiment and an abandoned field in 5-fold replication and prepared an average sample. Batches of $10 \mathrm{~g}$ each were put on sterile mortar and then the microorganisms were separated from the soil particles using the method of D. Zviagintsev. We prepared tenfold solutions of the output soil suspension, which were used for inoculations to the elective media for each ecological-trophic or taxonomic group of microorganisms. The quantitative compound of the microorganisms of the main ecological-trophic and taxonomic groups in soil was determined using the methods of inoculating the soil suspension to standard growth medias, which are generally accepted in soil microbiology (Zviahyntsev, 1991; Volkohon et al., 2010): microorganisms which use organic nitrogen - to meat infusion agar, Streptomyces and bacteria which use mineral nitrogen - to starch-and-ammonia agar, the number of pedotrophs - to soil agar), micromycetes - to Czapek medium, nitrifying bacteria - to starvation agar with ammonium-magnesium salt, microorganisms which synthesize polysaccharides to Martin medium, microorganisms which decompose humates - to medium with sodium humate, cellulosolytic microorganisms - with cellulose to Winogradsky media in Pushkinska modification. After the inoculation to the media, the bacteria were incubated at the temperature of $28{ }^{\circ} \mathrm{C}$ during $5-14$ days in relation to the tempi of growth of microorganisms of particular groups. The colonies which grew in these media were calculated on the assumption that one colony is formed from one vital cell. The number of microorganisms was expressed in colony-forming units per $1 \mathrm{~g}$ of absolutely dry soil. For this purpose, we determined the moisture of the soil samples for the experiments using the thermostat-gravimetric analysis, and recalculated the obtained number of colonies taking into consideration the coefficient of moisture and solution of the soil suspension. The inoculations were repeated three times, the obtained data were analyzed using mathematical statistics, calculating the confidence interval in the number of microorganisms. The content of total biomass of microorganisms in the soil was determined using the rehydration method by gentle drying-out of the soil samples at the temperature of $65-70{ }^{\circ} \mathrm{C}$ during 24 hours with following extraction of $0.5 \mathrm{M}$ using a solution of $\mathrm{K}_{2} \mathrm{SO}_{4}$ (Zviahyntsev, 1991).

To characterize the hydrothermal regime over the period of study, we used the values of monthly average air temperatures and the amount of precipitations, which were provided by the Oblast meteostations. To determine the impact of hydrothermal factors on the formation of the structure of soil microbiocenosis, we used the results of microbiological studies in the years which are characterized by a contrast in summer fluctuations of temperature of air and the amount of precipitations during the period of determination of the quantitative characteristics of the soil microbial group. For fuller analysis of thermal resources and atmospheric precipitations, we calculated the hydrothermal coefficient of G. Selianinov (HTC), which is adequate to the ratio of the sum of precipitations to 0.1 of the sum of the temperatures over the period with values higher than $10^{\circ} \mathrm{C}$ (Chirkov, 1979; Gathara et al., 2006). This parameter is more significant than the others and characterizes not only the income of the water balance (precipitations) but also non-productive discharge of moisture (evaporation) from the soil surface or vegetation and allows the evaluation of the impact of two abiotic factors at same time.

Mathematical analysis of the experimental data on formation of the structure and patterns in functioning of soil microbiocenoses under the impact of the studied factors which influence the biosystem processes in soils was conducted using the method of graph-analysis (Diestel, 2006; Vorobyov et al., 2006; Paulsn, 2009). This method is the most modern objective-informative source for enabling one to deal with qualitative and quantitative parameters and level out the impact of both occasional (for example, period of collecting samples), and complex mutually exclusive biosystem processes at the same time. The graph-analysis or graph of maximum coefficients of correlation (r) is based on the principle that the direct connections between the components of biological systems have the highest coefficient by the module, whereas mediated connections are lower by module and are calculated by multiplying the correlation coefficients of the corresponding direct connections. We studied the interaction of such elements as abiotic factors: soil type (chernozem, dark-grey, turfy-podzolized) usage of fertilizers (organic and mineral), hydrothermal regime over the period of study according to the values of hydrothermal coefficient (HTC); and biotic: content of the total biomass of microorganisms in the soil, number of microorganisms of different ecological-trophic and taxonomical groups. 


\section{Results}

Years of conducting monitoring studies of soil microbiocenoses in different agroecosystems resulted in a data base of the biological parameters of soils in Ukraine. Usage of a large part of experimental data on the microbiological condition of soils allowed us to develop an imitation mathematical model based on their graph-analysis. Such model allows visual demonstration of the systematization of the obtained results and focusing on the main factors which affect the development, condition and activity of microbiocenoses of different soils and illustrates the scheme of biological interactions. As a result, one obtains the most objective information on the structure of the microbial grouping and factors affecting the processes and trends in biological processes in soil (Zuur et al., 2007; Paulsn, 2009). The data obtained using graph-analysis usually reveal the structure and patterns of functioning of ecosystems of different levels (Diestel, 2006). In particular, this method was used in the analysis of the evolution of microbial life (Corel et al., 2016), analysis of gene-metabolic networks of soil microorganisms which convert remains of plants into humus substances (Vorobyov et al., 2011), evaluation of the microbiological condition of the soil agrolandscapes (Kutuzova et al., 2001), etc.

The calculations provided in the graph-scheme (Fig. 1a) indicate that in the conditions of deep chernozem, an 11-segment block of studied elements was formed, having a high level of correlational interactions. The core of the block was formed by the elements such as the content of total biomass of microorganisms in the soil and the microorganisms which utilize organic and mineral compounds of nitrogen, and primary producers of exopolysaccharide. Micromycetes,
Streptomyces, nitrifying microorganisms and those which decompose humates have only a single relation. It should be mentioned that the abiotic factors have only an indirect impact on the main block of interrelated soil microorganisms. Therefore, according to the position in the graph, the hydrothermal regime over the period of study had an insignificant effect on the activity of micromycetes, and cellulose-decomposing and pedotrophic microorganisms had no direct dependency on the complex of hydrothermal factors and these elements took independent positions on the graph.

Use of organic and mineral fertilizers activated the development of cellulose-decomposing microorganisms. Usage of mineral fertilizers in chernozem directly affected the development of autothonous microorganisms, i.e. pedotrophic, nitrifying and humate-decomposing. It should mentioned that using mineral fertilizers had only a tendentious pattern of impact on the activity of the microorganisms which form the core of the graph. The average results of the multi-year study indicated that similarly to the effect of hydrothermal factors (air temperature and moisture), using organic and mineral fertilizers in soils of agroecosystems is not an essential feature in the formation of the structure and functioning of the microbiocenosis in a chernozem-type soil. Therefore, the obtainned results of graph-analysis prove the peculiarities of the structure of chornozem microbiocenose which is a complex buffer system with stable constant rate of accurately identified microorganisms with tight trophic connections. The main block-forming feature was determined to be microorganisms - primary producers of exopolysaccharides, which have a close correlational connection with all trophic groups of microorganisms, for they are their component, and due to their high abundance significantly influence the total content of microbial biomass in the soil.
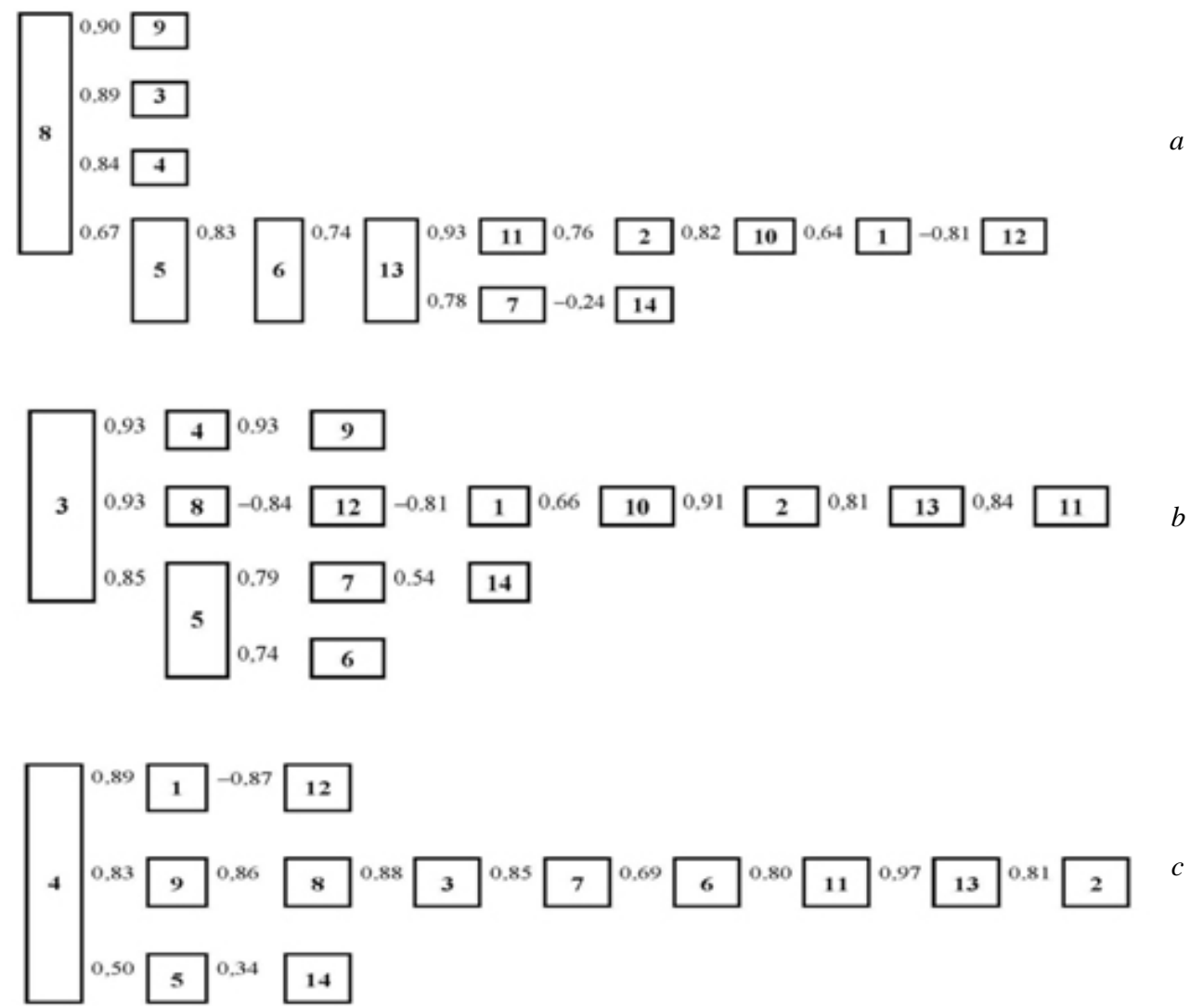

Fig. 1. Graph of maximum coefficients of correlation of biotic and abiotic factors for different types of soil: $a$ - deep chernozem; $b$ - dark grey; $c$ - turfy-podzolized: 1 - use of organic fertilizers; 2 - use of mineral fertilizers, 14 - hydrothermal coefficient (HTC); Biotic factors: 3 - content of total biomass of microorganisms, 4 - microorganisms which use organic nitrogen, 5 - microorganisms which use mineral nitrogen,

6-Streptomyces, 7 - micromycetes, 8 - microorganisms which synthesize exopolysaccharides, 9 - microorganisms which synthesize melanin,

10 - cellulolytic microorganisms, 11 - microorganisms which decompose humates, 12 - pedotrophic microorganisms, 13 - nitrifying microorganisms

Analysis of the graph of the studied parameters of dark-grey soil determined that the block of interrelated microorganisms (Fig. 1b) is also diverse and comprises 8 biotic and 2 abiotic elements. The biotransformational processes in the biosystem of dark-grey soil is demonstrated by the indicator of the content of total microorganism biomass, for it closely interrelates with most studied groups of microorganisms (microorganisms which use organic and mineral nitrogen, microorganisms which synthesize exopolysaccharides and melanin, micromycetes and pedotrophs). 
The hydrothermal regime parameter in dark-grey soil of an agroecosystem was the key factor for the taxonomic group of microorganisms with maximum biomass - micromycetes, whereas the other groups of microorganisms were affected by this factor only indirectly. Usage of organic and mineral fertilizers independently one from another formed direct connection with cellulose-decomposing microorganisms, for organic fertlisers are the source of high-molecular compounds for these decomposers, the activities of which depend on the mineral elements of nutrition.

Therefore, for agroecosystems with dark-grey type of soil, the content of total biomass of microorganisms is the main block-forming element of the kernel of the graph of strong correlational relations, which indicates the condition of a microbiocenosis and activity of the processes which occur in it, following the impact of the studied biotic and abiotic factors.

In turfy-podzolized soil, we found a dominating block which consisted of 8 interrelated elements (Fig. 1c) and had an intermediate position between two abovementioned types of soil. Microorganisms which utilize organic compounds of nitrogen were block-forming and had the maximum number of direct and indirect relations. The organic substance applied to soil directly affected the development and growth of the number of ammonificators with simultaneous inhibition of development of pedotrophs. The indicator of content of total biomass of microorganisms of the studied soil of the agroecosystem was formed directly by micromycetes and microorganisms which produce exopolysaccharides, due to the development of populations with large biomass (micromycetes) or high number (primary producers of exopolysaccharides) and their representation in different ecological-trophic groups of soil bacteria.

In a microbiocenosis of turfy-podzolized soil, we observed that the impact of organic fertilizers on the formation of trophic relations was the highest compared to the abovementioned biocenoses of other soils. It should be mentioned that hydrothermal factors had a low or direct impact on the microorganisms which utilize mineral compounds of nitrogen.

To prove or refute the impact of hydrothermal factors on the interaction of the microorganisms of different ecological-trophic groups and their role in biotransformation of the substances in the systems of different types of soil, we determined the impact separately for different years of study with contrast indicators of the hydrothermal regime. Therefore, during favourable weather conditions for functioning of microorganisms (HTC = 1.8), in the microbiocenosis of chernozem soil, we observed close correlational relations between practically all studied biotic and abiotic elements (Fig. 2a). The kernel of the graph consists of eutrophic microorganisms - Streptomyces, micromycetes and bacteria which are activated due to nutrient substrate in the form of organic and mineral fertilizers. As a result of activation of microbiological processes, the content of the total biomass of the microorganisms in the soil increases.

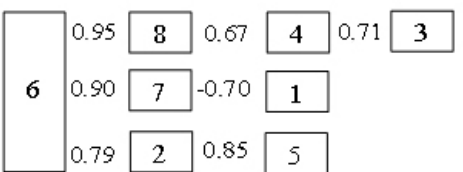

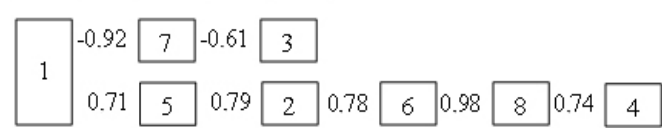

Fig. 2. Graph of maximum coefficients of correlation of biotic and abiotic factors for chernozem soil in relation to the value of HTC: the remarks are explained in Fig. 1

During unfavourable weather conditions (HTC $=0.4$ ), in the microbiocenosis of chernozem soil, the main trophic relations were disrupted, for the ammonifiers and Streptomyces which arrest the destructive function and lose the correlational relation after use of mineral fertilizers are removed from the kernels of active interaction. This can be explainned by the fact that the rise of the temperature causes restructuring of the microbial group towards microorganisms adaptive to increased temperatures and which have high tempi of breeding and which are less associated with moisture in the environment (Pettersson \& Baath, 2003; Romero-Olivares et al., 2017; Pandey et al., 2018). During the conditions of drought, micromycetes have reverse correlation with the organic substance and the content of the total biomass of microorganisms. This did not occur over the favourable conditions. Thus, it indicates the destabilisation of the functioning of the microbiocenosis. Only the microorganisms which assimilate mineral compounds of nitrogen remain in direct correlation with the mineral fertilizers $\left(\mathrm{r}_{5,2} \approx 0.8\right)$ in such conditions. To sum up the abovementioned material, we can come to a conclusion that in the block-graph of close correlational relations between the studied factors of a chernozem microbiocenosis during conditions of high air temperatures and insufficient moisture in the soil, only functionally significant relations weaken and change.

Analysis of the interrelations between the microorganisms of differrent ecological-trophic groups of dark-grey soil of the agroecosystem demonstrates that the conditions in the period of the study, which were close to the average values of the multi-year period $(\mathrm{HTC}=0.9)$ contributed to the formation of the united block with all 13 studied factors. The central kernel with positive correlational relations is formed by rhizomorph organisms (Streptomyces and micromycetes) with microorganisms which decompose humates and synthesize exopolysaccharides (Fig. 3a).

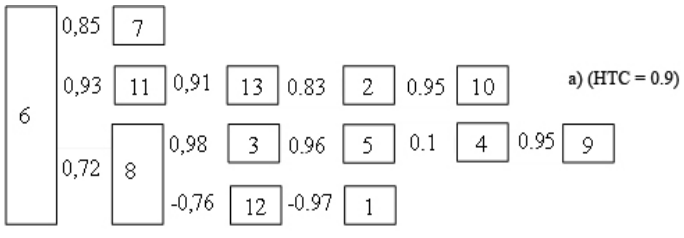

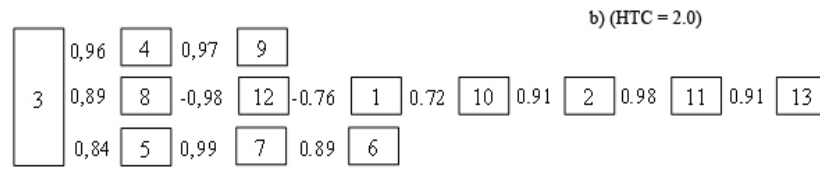

Fig. 3. Graph of maximum coefficients of correlation of biotic and abiotic factors for dark-grey soil depending on HTC: the explanations to the remarks are provided in Fig. 1

In the soil of the agroecosystem, we observed a high level of direct relation between the number of rhizomorph organisms of Streptomyces and micromycetes. This can be logically explained by the successive change of the taxonomic groups of microorganisms in the course of the decomposition of the organic substance. The parameter of the content of the biomass of microorganisms in dark-grey soil can be directly affected by the microorganisms which use mineral nitrogen or those which synthesize exopolysaccharides $\left(r_{5,8}=0.98\right)$. The mediated or lower impact on the content of the total microorganisms` biomass was caused by Streptomyces, ammonifiers and melanin-synthesizing microorganisms.

During the conditions of excessive moisture (HTC $=2.0$ ), we observed a formation of a 9-section block in the microbiocenosis (Fig. 3b) where the content of the total microorganisms' biomass was directly affected by the microorganisms which utilize organic and mineral compounds of nitrogen, synthesize exopolysaccharides and micromycetes. It should be mentioned that use of organic fertilizers in dark-grey soil decreased the development of pedotrophs and microorganisms which synthesize melanin. Therefore, the obtained data indicate that the absence of drought and excessive moisture of dark-grey soil ensures a more balanced functioning of its microbiocenosis. Stable interrelations occurred between the content of total microbial biomass, eutrophic microorganisms which use mineral and organic forms of nitrogen, and primary producers of exopolysaccharides in different variations.

During the period of study, in turfy-podzolized soil in the condition closest to the average multi-year parameters with moderate level of moisture, a graph-block with seven studied factors formed (Fig. 4a). The kernel of the correlational relations was formed by the microorganisms which depended on the organic fertilizers in the soil, i. e. microorganisms which use mineral forms of nitrogen and cause direct impact on the development of microorganisms which synthesize exopolysaccharides and melanin. 


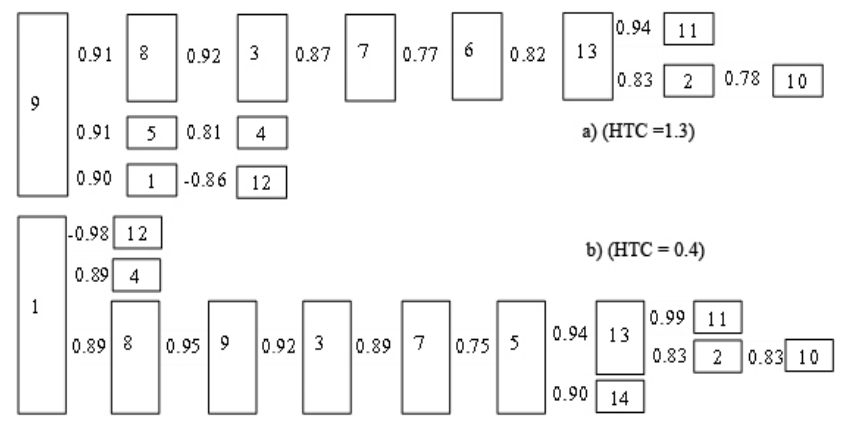

Fig. 4. Graph of maximum coefficients of correlations of biotic and abiotic factors for turfy-podzolized soil depending on the HTC: the explanations to the remarks are provided in Fig. 1

Heightened air temperature and drought (Fig. 6b) formed the kernel of active relations between only four studied factors. Usage of exogenous organic substance activated the development of ammonifiers and microorganisms which synthesize exopolysaccharides and melanin, i. e. most representatives of zymogenic microbiota. In such conditions, the development of autochthonous microbiota, particularly pedotrophs, decreased. However, the tendential pattern of the development of marker relations between the parameters of the content of the total microorganism biomass, eutrophic microorganisms and the primary producers of exopolysaccharides was observed throughout the experiment at differrent levels of hydrothermal regime.

The results of the study of the microbiocenosis of turfy-prodzolized soil indicate that the structure of the microbial group is significantly affected by the abiotic factors. The contrast in weather conditions caused a chaotic state in the interrelations between the main elements of the studied microbiocenosis.

\section{Discussion}

In the global context, the ecological problems of climate changes and their impact on the soil system and its microbiological component are one of the main topics of scientific research. This is related both to emissions of greenhouse gasses (Paustian et al., 2016), and formation of the main properties of soil (Schulz et al., 2013; Paul, 2014), including maintaining its organic substances, and provision of ecosystem functions (Ferris \& Tuomisto, 2015; Graham et al., 2016). According to the prognoses (Bardgett et al., 2013), climate changes manifested as increase in the frequency of droughts and heavy rainfall, increase in air temperature and concentration of carbon dioxide $\left(\mathrm{CO}_{2}\right)$ in the atmosphere will significantly affect the structure and functioning of microbial groupings.

Soil microbiota is a self-regulating system which forms at the level of soil aggregates and microzones which include mostly plant remains, humus complexes and minerals. At the same time, the main internal factor of change in the taxonomic and functional diversity of microbiota in soil is the vitality of the microorganisms, which causes qualitative changes in organic substances of soil through products of metabolism, causing restructuring of the microbial complex (Zviahyntsev, 1987). Therefore, changes occur in the taxonomic composition and physiological diversity in the soil microorganisms.

Taxonomic and functional diversity of soil microbiota is rather variable and depend both on internal patterns of decomposition processes and synthesis of organic matter and physical-chemical properties of the soil, and manifestation of natural processes, including climate change. This was also indicated by the results of our studies and the determined peculiarities in the forming of the structure of microbiocenoses of soils in relation to edaphic, hydrothermal and agrotechnical factors. Among the external abiotic factors of these changes, precipitations, periodic drying-out of the soil and temperature play the essential role. In soils oversaturated with moisture, the pores of soil aggregates become filled with water, the content of oxygen decreases, anaerobic processes develop, leading to restructuring of the entire microbial complex (Kozhevin, 2004). Recovery processes develop, causing formation of ferrous oxide and manganese oxide, hydrogen sulfide, organic acids and toxic compounds (Aristovskaya, 1980). On the other hand, drying-out of soil causes shrinkage of aggregates, narrowing of the space in pores, involvement of microorganisms in the matrix of organic-mineral gel, increase in the osmotic pressure of the interstitial water, which is usually concentrated in capillaries and membranes (Zviahyntsev, 1987). This reduces the biochemical activity of the microorganisms, disorders in the cycles of nitrogen and carbon in soil and leads to their partial death.

Microbial groupings in the soil are significant in the functioning of the agroecosystem. The impact of agrotechnical activity on the number of microorganisms of different ecological-trophic and physiological groups depends on the type of soil, compound of the agrochemicals, technologies of soil processing, etc. In particular, $\mathrm{pH}$ of soil (Wu et al., 2017; Zhao et al., 2018), moisture (Banerjee et al., 2016a), presence and availability of nutrients (Banerjee et al., 2016b) have been analysed as the main factors of impact on the diversity and the structure of soil microbiocenoses.

The changes in the structure of microbial cenosis of the soil in the process of change in hydrothermal parameters of the environment are being elucidated by the work of scientists. The temperature and the content of moisture in the soil are the essential factors which influence the soil biodiversity, decomposition of the organic compound and emission of greenhouse gasses in above-ground conditions (Kirshboum, 2006). Hydrothermal regime determines the tonus of vital activity of soil organisms, phytobiota, activity of biochemical processes of the soil (Suseela et al., 2012; McDaniel et al., 2013). In particular, bacteria react more quickly to the impulses of moisture, at the same time micromycetes grow slower and are slower in reacting to excessive moisture (Bell et al., 2008; Cregger et al., 2014). Also, drought increases the difference between the temperature sensitivity of rhizomorphic and bacterial groups (Briones et al., 2014). Even during slight changes in moisture (decrease by $30 \%$ of moisture), the group of soil micromycetes underwent changes in the dominating species, whereas the bacterial association retained unchanged. This indicates the higher flexibility of the bacterial groupings compared to micromycetes during non extreme dry cycles, whereas rhizomorph organisms were more flexible in the conditions of constant changes in the soil moisture (Kaisermann et al., 2015).

The temperature regulates the tempi of biogeochemical cycles in general. One of the impacts is determined by using the control of microbial metabolism. Increase in the temperature affects the change in metabolism over time, at the same time, the physiological processes of microbial groups adapt to the new temperature. Therefore, the trend of the physiological processes of the microorganisms of soil should be necessarily taken into account in predicting the biofeedbacks between the content of carbon in the soil and concentration of $\mathrm{CO}_{2}$ in the atomsphere during climate changes (Bradford, 2013; Pereira et al., 2013; Wood et al., 2013).

Microbial diversity in soil increases after the temperature rises to a certain level (around $26^{\circ} \mathrm{C}$ ) (Zhou et al., 2016). During extreme high temperature conditions, drought and low soil moisture, the diversity of microorganisms rapidly decreases. At the same time, the structure of prokaryote groups changes, which indicates significant change in the activity of microbiota, possible appearance of thermophilic forms of microorganisms and intensifying of the enzymic processes in the gradient of soil temperature, which provides high emission of greenhouse gases $\left(\mathrm{CO}_{2}, \mathrm{~N}_{2} \mathrm{O}, \mathrm{CH}_{4}\right)$ (Kruglov et al., 2012).

Depending on which factor reduces the productivity of ecosystems, for example precipitation, and changes in the soil moisture respectively, the factors can increase or decrease the ratio of the number of bacteria and micromycetes, and also change the composition of their groups. It was determined that different conditions of soil moisture lead to changes in the structure of bacterial and rhizomorph community (Brockett et al., 2012) and bacterial and eukaryote community (Li et al., 2017). A low level of soil moisture reduces the spread of microorganisms (Carson et al., 2010; Kravchenko et al., 2013).

It was determined that on the regional scale, change in moisture and usage of soil is most closely related to the composition of the microbial group and biomass of microorganisms, whereas the total content of carbon in the soil and the impact of climate are less related, but still related significantly. The factors such as spatial structure, soil structure, presence of nutrients and plant species were insignificant (Ma et al., 2015). 
However, there are very few results of experiments and research on the impact on the microbial groups and their reactive response to many factors of changes in climatic parameters. For example, increase in the concentration of $\mathrm{CO}_{2}$ in the atmosphere and precipitation can increase the moisture of soil in the ecosystem, but this can be reduced by rise in temperature (Dermody et al., 2007). Also, warming can activate the microbial activity in the ecosystem, though this can be avoided due to absence (deficiency) of sufficient amount of precipitation, which causes drying of the soil. For example, microbial activity is reduced during high temperatures due to the access of microorganisms to the available substrate (Zak et al., 1999). Such interactive effects of climatic factors in the context of a number of factors are poorly studied for natural plant groups (Norby \& Luo, 2004), and studied even less for microbiocenoses of soil. In such conditions, to characterize the complex of the impact of natural factors (combining factors of temperature and moisture) and different objects, research broadly uses hydrothermal coefficient (Taparauskiene \& Miseckaite, 2017), and also methods of mathematical modeling.

Despite the fact that the impact of different factors on a group of microorganisms in the soil and their activity has been the object of a number of studies, there remain many undetermined details in the stability of microbial groupings in the soil and the consequences of the changes in a microbiocenosis regarding their ability to resist further changes. However, the changes in the value or the relative contributions of the group members can have consequences for the resistance of the microbial grouping and these changes in the structure can be unclear during determination of the main microbial properties and ecological condition of soils (Griffiths \& Philippot, 2013).

Considering the abovementioned results of multi-year studies on microbial groups of three types of soil subject to different systems of fertilizing and impact of hydrothermal factors using the method of graph-analysis, we determined that the most informative parameters which provide information on the formation of the soil microbiocenosis, microbiological processes in it and the ecological condition of soil in the agroecosystem is the content of the total biomass of microorganisms and the number of microorganisms which use organic and mineral nitrogen. The relations between them were the most stable under any hydrothermal conditions or different types of fertilizer used. According to the abovementioned and the earlier determined facts for evaluating the changes in the ecological condition of soil, we state that the biodiagnostical criteria should be as follows: the content of the total biomass of microorganisms and the coefficients of mineralization - immobilization, oligotrophy, pedotrophy and humus-accumulation, which are essentially the ratio of the number of the corresponding trophic groups of microorganisms (Andreyuk, 1981; Sherstoboeva et al., 2008; Stefurak et al., 2016).

\section{Conclusion}

The soil of agroecosystems of chernozem type is a complex system with constant rate of clearly determined microorganisms of certain trophic groups which ensure the buffer state of a microbiocenosis. The impact of hydrothermal factors on the structure of a soil microbiocenosis is lower compared to other types of soils. In dark-grey soil of the agroecosystem, the total content of biomass of microorganisms characterizes the condition of microbiocenosis in general and the processes within it. Regardless of the change of hydrothermal regime during the period of study, stable interrelations occurred between the total content of biomass of microorganisms, microorganisms which use organic and mineral nitrogen and microorganisms which synthesize exopolysaccharides. The microbiocenosis of turfy-podzolized soil clearly reacted to fertilizers and change in the hydrothermal factors. The contrast of weather conditions in the studied microbiocenosis caused a chaotic state of interrelations between the main studied biotic and abiotic factors. We observed throughout the experiment a tendency towards development of marker relations between the total content of biomass of microorganisms, microorganisms which use organic and mineral nitrogen and microorganisms which synthesize exopolysaccharides. Using graph-analysis, we proved that the assessment of the ecological state of soil and the impact of the agrarian procedures it is subjected to is best conducted using the parameters of the total content of biomass of microorganisms in the soil and the ratio between the numbers of microorganisms which form the kernel of the graph.

\section{References}

Aislabie, J. A., \& Deslippe, J. (2013). Soil microbes and their contribution to soil services. In: Dymond, J. R. (Ed.). Ecosystem services in New Zealand conditions and trends. Manaaki Whenua Press, New Zealand. Pp. 143-161.

Aitkenhead, M. (2016). Modelling soil ecosystem services. In: Sang, N., \& OdeSang, A. (Ed). A review on the state of the art in scenario modelling for environmental management. Naturvardsverket, Environmental Protection Agency, Stockholm. Pp. 65-74.

Andreyuk, E. A. (1981). Metodologicheskiye aspekty izucheniya mikrobnykh soobshchestv pochv [Methodological aspects of studying microbial communities of soils]. In: Andreyuk, E. A. (Ed). Microbial communities and their functioning in soil. Naukova Dumka, Kyiv. Pp. 13-28 (in Russian).

Aristovskaya, T. V. (Ed.). (1980). Mikrobiologiya protsessov pochvoobrazovaniya [Microbiology of soil formation processes]. Nauka, Leningrad (in Russian).

Banerjee, S., Helgason, B., Wang, L., Winsley, T., Ferrari, B. C., \& Siciliano, S. D. (2016a). Legacy effects of soil moisture on microbial community structure and $\mathrm{N}_{2} \mathrm{O}$ emissions. Soil Biology and Biochemistry, 95, 40-50.

Banerjee, S., Kirkby, C. A., Schmutter, D., Bissett, A., Kirkegaard, J. A., \& Richardson, A. E. (2016b). Network analysis reveals functional redundancy and keystone taxa amongst bacterial and fungal communities during organic matter decomposition in an arable soil. Soil Biology and Biochemistry, 97, 188-198.

Barberan, A., Bates, S. T., Casamayor, E. O., \& Fierer, N. (2012). Using network analysis to explore co-occurrence patterns in soil microbial communities. Intemational Society for Microbial Ecology Journal, 6(2), 343-351.

Bardgett, R. D., Manning, P., Morriën, E., \& De Vries, F. T. (2013). Hierarchical responses of plant-soil interactions to climate change: Consequences for the global carbon cycle. Journal of Ecology, 101, 334-343.

Bell, C., McIntyre, N., Cox, S. Tissue, D., \& Zak, J. (2008). Soil microbial responses to temporal variations of moisture and temperature in a Chihuahuas Desert grassland. Microbial Ecology, 56, 153-167.

Bissett, A., Brown, M. V., Siciliano, S. D., \& Thrall, P. H. (2013). Microbial community responses to anthropogenically induced environmental change: towards a systems approach. Ecology Letters, 16, 128-139.

Bradford, M. A., \& Fierer, N. (2012). The biogeography of microbial communities and ecosystem processes: Implications for soil and ecosystem models. In: Wall, D. H., Bardgett, R. D., Behan-Pelletier, V., Herrick, J. E., Jones, H., Ritz, K., Six, J., Strong, D. R., \& van der Putten, W. H. (Eds.). Soil Ecology and Ecosystem Services. Oxford University Press, Oxford, UK. Pp. 189-200.

Bradford, M. A. (2013). Thermal adaptation of decomposer communities in warming soils. Frontiers in Microbiology, 4, 333.

Briones, M. J. I., McNamara, N. P., Poskitt, J., Crow, S. E., \& Ostle, N. J. (2014). Interactive biotic and abiotic regulators of soil carbon cycling: Evidence from controlled climate experiments on peatland and boreal soils. Global Change Biology, 20(9), 2971-2982.

Brockett, B. F. T., Prescott, C. E., \& Grayston, S. J. (2012). Soil moisture is the major factor influencing microbial community structure and enzyme activities across seven biogeoclimatic zones in western Canada. Soil Biology and Biochemistry, 44, 9-20.

Bui, E. N., \& Henderson, B. L. (2013). C : N : P stoichiometry in Australian soils with respect to vegetation and environmental factors. Plant Soil, 373, 553-568.

Calzolari, C., Ungaro, F., Filippi N., Guermandi, M., Malucelli, F., Marchi, N., Staffilani, F., \& Tarocco, P. (2016). A methodological framework to assess the multiple contributions of soils to ecosystem services delivery at regional scale. Geoderma, 261, 190-203.

Carson, J. K., Gonzalez-Quinones, V., Murphy, D. V., Hinz, C., Shaw, J. A., \& Gleeson, D. B. (2010). Low pore connectivity increases bacterial diversity in soil. Applied and Environmental Microbiology, 76(12), 3936-3942.

Corel, E., Lopez, P., Meheust, R., \& Bapteste, E. (2016). Network-Thinking: Graphs to analyze microbial complexity and evolution. Trends Microbiology, 24(3), 224-237.

Chirkov, Y. I. (1979). Use of agroclimatology in crop distribution. In: Seemann, J., Chirkov, Y. I., Lomas, J., \& Primault, B. (Eds.). Agrometeorology. SpringerVerlag Berlin Heidelberg, New York. Pp. 317-320.

Cregger, M. A., Sanders, N. J., Dunn, R. R., \& Classen, A. T. (2014). Microbial communities respond to experimental warming, but site matters. PeerJ, 2, 358.

De Vries, F. T., \& Shade, A. (2013). Controls on soil microbial community stability under climate change. Frontiers in Microbiology, 4, 265.

Demyanyuk, O. S., Symochko, L. Y., \& Tertychna, O. V. (2017). Suchasni metodychni pidkhody do otsiniuvannia ekolohichnoho stanu gruntu za aktyvnistiu mikrobiotsenozu [Modern methodological approaches to evaluation of the 
ecological condition of soil by microbial activity]. Problems of Bioindications and Ecology, 22(1), 55-68 (in Ukrainian).

Dermody, O. I., Weltzin, J. F., Engel, E. C., Allen, P., \& Norby, R. J. (2007). How do elevated $\left[\mathrm{CO}_{2}\right]$, warming, and reduced precipitation interact to affect soil moisture and LAI in an old field ecosystem? Plant Soil, 301, 255-266.

Diestel, R. (2006). Graph theory. Springer Science \& Business Media, Berlin.

Ferris, H., \& Tuomisto, H. (2015). Unearthing the role of biological diversity in soil health. Soil Biology and Biochemistry, 85, 101-109.

Gathara, S. T., Gringof, L. G., Mersha, E., Sinha Ray, K. C., \& Spasov, P. (2006) Impacts of desertification and drought and other extreme meterological events. Word meteorological organization commission for agricultural meteorology. Report No. 101, Geneva, Switzerland.

Geisseler, D., \& Scow, K. M. (2014). Long-term effects of mineral fertilizers on soil microorganisms: A review. Soil Biology and Biochemistry, 75, 54-63.

Gottfried, M., Pauli, H., Futschik, A., Akhalkatsi, M., Barančok, P., Alonso, J. L. B., Coldea, G., Dick, J., Erschbamer, B., Calzado, M. R. F., Kazakis, G., Krajci, J. Larsson, P., Mallaun, M., Michelsen, O., Moiseev, D., Moiseev, P., Molau, U., Merzouki, A., Nagy, L., Nakhutsrishvili, G., Pedersen, B., Pelino, G., Puscas, M., Rossi, G., Stanisci, A., Theurillat, J.-P., Tomaselli, M., Villar, L., Vittoz, P., Vogiatzakis, I., \& Grabherr, G. (2012). Continent-wide response of mountain vegetation to climate change. Nature Climate Change, 2, 111-115.

Graham, E. B., Knelman, J. E., Schindlbacher, A., Siciliano, S., Breulmann, M., Yannarell, A., Beman, J. M., Abell, G., Philippot, L., Prosser, J., Foulquier, A., Yuste, J. C., Glanville, H. C., Jones, D. L., Angel, R., Salminen, J., Newton, R. J., Bürgmann, H., Ingram, L. J., Hamer, U., Siljanen, H. M. P., Peltoniemi, K., Potthast, K., Bañeras, L., Hartmann, M., Banerjee, S., Yu, R-Q., Nogaro, G., Richter, A., Koranda, M., Castle, S. C., Gobema, M., Song, B., Chatterjee, A., Nunes, O. C., Lopes, A. R., Cao, Y., Kaisermann, A., Hallin, S., Strickland, M. S., Garcia-Pausas, J., Barba, J., Kang, H., Isobe, K., Papaspyrou, S., Pastorelli, R., Lagomarsino, A., Lindström, E. S., Basiliko, N., \& Nemergut, D. R. (2016). Microbes as engines of ecosystem function: when does community structure enhance predictions of ecosystem processes? Frontiers Microbiology, 7, 214.

Griffiths, B. S., \& Philippot, L. (2013). Insights into the resistance and resilience of the soil microbial community. Federation of European Microbiological Societies. Microbiology Reviews, 37, 112-129.

Hydbom, S., Ernfors, M., Birgander, J., Hollander, Jensen, E. S., \& Olsson, P. A (2017). Reduced tillage stimulated symbiotic fungi and microbial saprotrophs, but did not lead to a shift in the saprotrophic microorganism community structure. Applied Soil Ecology. 119, 104-114.

Kaisermann, A., Maron, P., Beaumelle, L., \& Lata, J. C. (2015). Fungal communities are more sensitive indicators to non-extreme soil moisture variations than bacterial communities. Applied Soil Ecology, 86, 158-164.

Kirschboum, M. U. F. (2006). The temperature dependence of organic-matter decomposition - still a topic of debate. Soil Biology and Biochemistry, 38(9), 2510-2518.

Konopka, A., Lindemann, S., \& Fredrickson, J. (2015). Dynamics in microbial communities: Unraveling mechanisms to identify principles. International Society for Microbial Ecology Journal, 9(7), 1488-1495.

Kozhevin, P. A. (2004). Ekologiya pochvennykh mikroorganizmov [Ecology of soil microorganisms]. In: Netrusov, A. I. (Ed.). Ecology of microorganisms. Akademiya, Moscow. Pp. 71-94 (in Russian).

Kravchenko, A., Chun, H. C., Mazer, M., Wang, W., Rose, J. B., Smucker, A., \& Rivers, M. (2013). Relationships between intra-aggregate pore structures and distributions of Escherichia coli within soil macro-aggregates. Applied Soil Ecology, 63, 134-142.

Kruglov, Y. V., Umarov, M. M., Mazirov, M. A., Khokhlov, N. F., Patyka, N. V. Dumova, V. A., Andronov, E. E., Kostina, N. V., Golichenkov, M. V. (2012) Izmeneniye agrofizicheskikh svoystv i mikrobiologicheskikh protsessov dernovo-podzolistoy pochvy v ekstremalnykh usloviyakh vysokoy temperatury i zasukhi [Changes in both agro-physical properties and microbiological processes of sod-podzolic soils under extreme conditions of high temperature and drought]. Izvestiya of Timiryazev Agricultural Academy, 3, 79-87 (in Russian).

Kuramae, E. E., Yergeau, E. M., Wong, L. C., Pijl, A. S., van Veen, J. A., \& Kowalchuk, G. A. (2012). Soil characteristics more strongly influence soil bacterial communities than land-use type. Microbial Ecology, 79(1), 12-24.

Kutuzova, R. S., Sirota, L. B., Orlova, O. V., \& Vorobyov, N. I. (2001). Ispolzovaniye matematicheskogo analiza dlya otsenki mikrobiologicheskogo sostoyaniya pochv agrolandshaftnogo opyta [The use of mathematical analysis to assess the microbiological state of soils agrolandscape experience]. Agricultural Chemistry, 1, 19-33 (in Russian).

Langley, J. A., \& Hungate, B. A. (2014). Plant community feedbacks and long-term ecosystem responses to multi-factored global change. AoB Plants, 6, 24-27.

Lesaulnier, C., Papamichail, D., McCorkle, S., Ollivier, B., Skiena, S., Taghavi, S., Zak, D., \& van der Lelie, D. (2008). Elevated atmospheric $\mathrm{CO}_{2}$ affects soil microbial diversity associated with trembling aspen. Environmental Microbiology, 10(4), 926-941.
Li, Y., Adams, J., Shi, Y., Wang, H., He, J.-S., \& Chu, H. (2017). Distinct soil microbial communities in habitats of differing soil water balance on the Tibetan Plateau. Scientific Reports, 7, 46407.

Loreau, M., \& de Mazancourt, C. (2013). Biodiversity and ecosystem stability: A synthesis of underlying mechanisms. Ecology Letters, 16, 106-115.

Ma, L., Guo, C., Lü, X., Yuan, S., \& Wang, R. (2015). Soil moisture and land use are major determinants of soil microbial community composition and biomass at a regional scale in Northeastern China. Biogeosciences, 12, 2585-2596.

McDaniel, M. D., Kaye, J. P., \& Kaye, M. W. (2013). Increased temperature and precipitation had limited effects on soil extracellular enzyme activities in a post-harvest forest. Soil Biology and Biochemistry, 56, 90-98.

Nannipieri, P., Ascher, J., Ceccherini, M. T., Landi, L., Pietramellara, G., \& Renella, G. (2017). Microbial diversity and soil functions. European Journal of Soil Science, 68(1), 12-26.

Norby, R. J., \& Luo, Y. Q. (2004). Evaluating ecosystem responses to rising atmospheric $\mathrm{CO}_{2}$ and global warming in a multi-factor world. New Phytologist, 162, 281-293.

Pandey, S. N., Abid, M., \& Khan, M. M. A. A. (2018). Diversity, functions, and stress responses of soil microorganisms. In: Egamberdieva, D., \& Ahmad, P. (Eds.). Plant microbiome: Stress response. Microorganisms for Sustainability, 5, 1-19.

Paul, E. A. (2014). Soil microbiology, ecology and biochemistry. Academic Press, London, UK.

Paulsn, D. S. (2009). Biostatistics and microbiology: A survival manual. Springer, New York, USA

Paustian, K., Lehmann, J., Ogle, S., Reay, D., Robertson, G. P., \& Smith, P. (2016). Climate-smart soils. Nature, 532, 49-57.

Pereira, E. I. P., Chung, H., Scow, K., \& Six, J. (2013). Microbial communities and soil structure are affected by reduced precipitation, but not by elevated carbon dioxide. Soil Science Society of America Journal, 77(2), 482-488.

Pettersson, M., \& Baath, E. (2003). Temperature-dependent changes in the soil bacterial community in limed and unlimed soil. Federation of European Microbiological Societies. Microbiology Ecology, 45(1), 13-21.

Rehman, K., Ying, Z., Andleeb, S., Jiang, Z., \& Olajide, E. K. (2016). Short term influence of organic and inorganic fertilizer on soil microbial biomass and DNA in summer and spring. Journal of Northeast Agricultural University, 23(1), 20-27.

Romero-Olivares, A. L., Allison, S. D., \& Treseder, K. K. (2017). Soil microbes and their response to experimental warming over time: A meta-analysis of field studies. Soil Biology and Biochemistry, 107, 32-40.

Schulz, S., Brankatschk, R., Dümig, A., Kögel-Knabner, I., Schloter, M., \& Zeyer, J. (2013). The role of microorganisms at different stages of ecosystem development for soil formation. Biogeosciences, 10, 3983-3996.

Sheibani, S., \& Ahangar, A. G. (2013). Effect of tillage on soil biodiversity. Journal of Novel Applied Sciences, 2(8), 273-281.

Sherstoboeva, E. V., Chabaniuk, Y. V., \& Fedak, L. I. (2008). Bioindikatsiya ekologicheskogo sostoyaniya pochv ekosistem [Bioindication of soil ecological consistence]. Agricultural Microbiology, 7, 48-56 (in Russian).

Sherstoboeva, O., Demyanyuk, O., \& Chabanyuk, Y. (2017). Biodiahnostyka biobezpeka gruntiv ahroekosystem [Biodiagnostics and bio-security of soils of agroecosystems]. Agroecological Journal, 2, 142-148 (in Ukrainian).

Singh, B. K., Bardgett, R. D., Smith, P., \& Reay, D. S. (2010). Microorganisms and climate change: Terrestrial feedbacks and mitigation options. Nature Reviews Microbiology, 8, 779-790.

Song, H.-S., Cannon, W. R., Beliaev, A. S., \& Konopka, A. (2014). Mathematical modeling of microbial community dynamics: A methodological review. Processes, 2(4), 711-752.

Stefurak, V. P., Nakonechna, S. P., \& Baskevich, O. V. (2016). Monitorynh zabrudnennia dovkillia $\mathrm{v}$ zoni dii pidpryiemstv khimichnoi promyslovosti z vykorystanniam bioindykatoriv [Monitoring of environmental pollution in the area of chemical industry enterprises by means of bioindicators]. Scientific Issues Ternopil Volodymyr Hnatiuk National Pedagogical University, Series: Biology, 1, 95-101 (in Ukrainian).

Stegen, J. C., Lin, X., Fredrickson, J. K., Chen, X., Kennedy, D. W., Murray, C. J., Rockhold, M. L., \& Konopka, A. (2013). Quantifying community assembly processes and identifying features that impose them. International Society for Microbial Ecology Journal, 7(11), 2069-2079.

Steinweg, J. M., Dukes, J. S., Paul, E. A., \& Wallenstein, M. D. (2013). Microbial responses to multi-factor climate change: Effects on soil enzymes. Frontiers in Microbiology, 4, 146

Suseela, V., Conant, R. T., Wallenstein, M. D., \& Dukes, J. S. (2012). Effects of soil moisture on the temperature sensitivity of heterotrophic respiration vary seasonally in an old-field climate change experiment. Global Change Biology, 18, 336-348.

Taparauskiene, L., \& Miseckaite, O. (2017). Comparison of watermark soil moisture content with Selyaninov hydrothermal coefficient. Agrofor Intemational Joumal, 2(2), 106-115. 
Thibaut, L. M., \& Connolly, S. R. (2013). Understanding diversity-stability relationships: Towards a unified model of portfolio effects. Ecology Letters, 16(2), 140-150.

Torsvik, V., \& Ovreas, L. (2002). Microbial diversity and function in soil: From genes to ecosystems. Current Opinion in Microbiology, 5, 240-245.

Treonic, A. M., Austin, E. E., Buyer, J. S., Maul, J. E., Spicer, L., \& Zasada, I. A. (2010). Effects of organic amendment and tillage on soil microorganisms and microfauna. Applied Soil Ecology, 46(1), 103-110.

Tsiafouli, M. A., Thebault, E., Sgardelis, S. P., de Ruiter, P. C., van der Putten, W. H., Birkhofer, K., Hemerik, L., de Vries, F. T., Bardgett, R. D., Brady, M. V., Bjornlund, L., Jorgensen, H. B., Christensen, S., Hertefeldt, T., Hotes, S., Hol, W. H. G., Frouz, J., Liiri, M., Mortimer, S. R., Setala, H., Tzanopoulos, J., Uteseny, K., Pizl, V., Stary, J., Wolters, V., \& Hedlund, K. (2015). Intensive agriculture reduces soil biodiversity across Europe. Global Change Biology, 21(2), 973-985.

Van der Putten, W. H. (2012). Climate change, aboveground-belowground interactions, and species range shifts. Annual Review of Ecology, Evolution and Systematics, 43, 365-383.

Vereecken, H., Schnepf, A., Hopmans, J. W., Javaux, M., Or, D., Roose, T., Vanderborght, J., Young, M. H., Amelung, W., Aitkenhead, M., Allison, S. D., Assouline, S., Baveye, P., Berli, M., Brüggemann, N., Finke, P., Flury, M. Gaiser, T., Govers, G., Ghezzehei, T., Franssen, H. J. H., Heppell, J., Horn, R., Huisman, J. A., Jacques, D., Jonard, F., Kollet, S., Lafolie, F., Lamorski, K., Leitner, D., Mcbratney, A., Minasny, B., Montzka, C., Nowak, W., Pachepsky, Y., Padarian, J., Romano, N., Roth, K., Rothfuss, Y., Rowe, E. C., Schwen, A., Šimůnek, J., Tiktak, A., Van Dam, J., van der Zee, S. E. A. T. M., Vogel, H. J., Vrugt, J. A., Wöhling, T., Young, I. M., \& Tiktak, A. (2016) Modeling soil processes: Review, key challenges, and new perspectives. Vadose Zone Journal, 15(5), 1-57.

Volkohon, V. V., Nadkemychna, O. V., Tokmakova, L. M., Melnychuk, T. M., Chaikovska, L. O., Nadkernychnyi, S. P., Sherstoboiev, M. K., Kozar, S. F., Kopylov, Y. P., Krutylo, D. V., Parkhomenko, T. I., Kamienieva, I. O., Adamchuk-Chala, N. I., Kovalevska, T. M., Didovych, S. V., Volkohon, K. I., Pyshchur, I. M., Volkohon, M. V., Dimova, S. B., \& Komok, M. S. (2010). Eksperymentalna gruntova mikrobiolohiia [Experimental soil microbiology] Agrarian Science, Kyiv (in Ukrainian).

Vorobyov, N. I., Sviridova, O. V., \& Kutuzova, R. S. (2006). Metodicheskiye rekomendatsii po ispolzovaniyu graf-analiza $\mathrm{v}$ issledovaniyakh sistem, sostoyashchikh iz bioticheskikh i abioticheskikh komponentov [Methodological recommendations on the use of graph analysis in studies of systems consisting of biotic and abiotic components]. St. Petersburg-Pushkin (in Russian).

Vorobyov, N. I., Sviridova, O. V., Popov, A. A., Rusakova, I. V., \& Petrov, V. B. (2011). Graf-analiz genno-metabolicheskikh setey pochvennykh mikroorganizmov, transformiruyushchikh rastitelnyye ostatki v gumusovyye veshchestva [Graph-analysis in gene-metabolic networks of soil microorganisms which transformed plant residues to humus substances]. Agricultural Biology, 3, 88-93 (in Russian).

Wall, D. H., Bardgett, R. D., Behan-Pelletier, V., Herrick, J. E., Jones, T. H., Ritz, K., Six, J., Strong, D. R., \& Van der Putten, W. H. (2012). Soil ecology and ecosystem services. Oxford University Press, Oxford.

Walther, G. R., Post, E., Convey, P., Menzel, A., Parmesan, C., Beebee, T. J., Fromentin, J. M., Hoegh-Guldberg, O., \& Bairlein, F. (2002). Ecological responses to recent climate change. Nature, 416(6879), 389-395.

Wood, J. D., Gordon, R. J., \& Wagner-Riddle, C. (2013). Biases in discrete CH and $\mathrm{N}_{2} \mathrm{O}$ sampling protocols associated with temporal variation of gas fluxes from manure storage systems. Agriculural and Forest Meteorology, 171172, 295-305.

Wu, Y., Zeng, J., Zhu, Q., Zhang, Z., \& Lin, X. (2017). pH is the primary determinant of the bacterial community structure in agricultural soils impacted by polycyclic aromatic hydrocarbon pollution. Scientific Reports, 7, srep40093.

Xiong, J. B., Sun, H., Peng, F., Zhang, H., Xue, X., Gibbons, S. M., Gilbert, J. A., \& Chu, H. (2014). Characterizing changes in soil bacterial community structure in response to short-term warming. Federation of European Microbiological Societies. Microbiology Ecology, 89, 281-292.

Zak, D. R., Holmes, W. E., MacDonald, N. W., \& Pregitzer, K. S. (1999). Soil temperature, matric potential, and the kinetics of microbial respiration and nitrogen mineralization. Soil Science Society of American Joumal, 63, 575-584.

Zhao, C., Fu, S., Mathew, R. P., Lawrence, K. S., \& Feng, Y. (2015). Soil microbial community structure and activity in a 100-year-old fertilization and crop rotation experiment. Journal of Plant Ecology, 8(6), 623-632.

Zhao, S., Liu, J.-J., Banerjee, S., Zhou, N., Zhao, Z.-Y., Zhang, K., \& Tian, C.-Y. (2018). Soil pH is equally important as salinity in shaping bacterial communities in saline soils under halophytic vegetation. Scientific Reports, 8, 4550.

Zhou, J., Deng, Y., Shen, L., Wen, C., Yan, Q., Ning, D., Qin, Y., Xue, K., Wu, L., He, Z., Voordeckers, J. W., Van Nostrand, J. D., Buzzard, V., Michaletz, S. T., Enquist, B. J., Weiser, M. D., Kaspari, M., Waide, R., Yang, Y., \& Brown, J. H. (2016). Temperature mediates continental-scale diversity of microbes in forest soils. Nature Communications, 7, 12083.

Zornoza, R. Guermero, C. Mataix-Solera, J., Scow, K. M, Arcenegui, V. \& MataixBeneyto, J. (2009). Changes in soil microbial community structure following the abandonment of agricultural terraces in mountainous areas of Eastern Spain. Applied Soil Ecology, 42(3), 315-323.

Zuur, A. K., Ieno, E. N., \& Smith, G. M. (2007). Analysing ecological data. Springer-Verlag, New-York.

Zviahyntsev, D. H. (1987). Pochva i mikroorganizmy [Soil and microorganisms]. Moscow State University, Moscow (in Russian).

Zviahyntsev, D. H. (1991). Metody pochvennoy mikrobiologii i biokhimii [Methods of soil microbiology and biochemistry]. Moscow State University, Moscow (in Russian). 